\title{
Analisis Fungsi Bahasa dalam Komunikasi Adat Bejeghum: Kajian Sosiopragmatik
}

\author{
${ }^{1}$ Febi Junaidi*, ${ }^{2}$ Empep Mustopa, ${ }^{3}$ Ari Putra, ${ }^{4}$ Sani Aryanto \\ ${ }^{1}$ Universitas Sebelas Maret, ${ }^{2}$ SMK Negeri 1 Ketapang, ${ }^{3}$ Universitas Ibn Khaldun Bogor, \\ ${ }^{4}$ Universitas Bhayangkara Jakarta Raya
}

Pengiriman: 02/11/2020; Diterima: 12/11/2020; Publikasi: 23/11/2020

DOI: $10.31629 /$ jermal.v1i2.2709

\begin{abstract}
Abstrak
Bejeghum merupakan salah satu kebudayaan yang ada di Bengkulu Selatan. Kegiatan bejeghum dilakukan pada berbagai konteks. Pada pelaksanaannya, seseorang akan datang ke rumah setiap masyarakat di Kedurang dengan tujuan untuk mengundang agar hadir pada kegiaatn tertentu. Bejeghum dilakukan oleh seorang perempuan, bukan oleh laki-laki. Penelitian ini bertujuan untuk mendeskripsikan berbagai jenis bejeghum dan fungsi bahasa pada komunikasi yang dilakukan saat bejeghum. Metode yang digunakan pada penelitian ini adalah metode kualitatif. Data dikumpulkan dengan cara observasi dan wawancara. Tahapan teknik analisis data meliputi pengumpulan data, pemilihan data, penafsiran data, dan penyimpulan. Hasil penelitian ini menunjukkan bahwa budaya bejeghum terdiri atas banyak jenis seperti bejeghum saat acara bahagia dan bejeghum saat adanya berita duka. Bejeghum saat ada yang menikah, meninggal dunia, syukuran, dan bejeghum untuk kegiatan kebudayaan tertentu. Lebih jauh, bahasa yang digunakan dapat berupa permohonan, perintah, undangan, dan pemberitahuan. Hal ini menunjukkan bahwa bejeghum memiliki banyak karakteristik berdasarkan tujuannya.
\end{abstract}

Kata Kunci: bejeghum, fungsi bahasa, sosiopragmatik.

\section{PENDAHULUAN}

Indonesia memiliki beragam bahasa daerah yang khas dan unik. Bahasa tersebut digunakan sebagai sarana berkomunikasi masyarakat dalam kehidupan sehari-hari sebab bahasa memiliki peranan penting dalam segala aspek kehidupan manusia. Bahasa juga merupakan kunci utama dalam kegiatan komunikasi yang dimiliki oleh manusia dalam berianteraksi dengan sesama (Sari, 2012). Language is the essential means for an someone to express themselves in their social life, and communicate and interact with other poople (Biçer, 2017).

Bahasa dalam kehidupan manusia juga memiliki keberagaman konteks penggunaannya. Language is a system involving complex communication, either spo-ken or written, to express ideas and feelings. Pragmatics, or the appropriate useof a language in situational contexts, is the nexus of language and culture (Oxford \& Gkonou, 2018). Senada dengan hal di atas, language and culture are two inseparable entities.Therefore, learning a language is at once learning the culture of the people using it (Nadera, 2018).

Salah satu aktivitas masyarakat yang memerlukan bahasa adalah pola interaksi jual beli di pasar. Pada konteks ini tentunya bahasa memiliki peranan penting. Sorang pembeli dan penjual tentunya akan memakai berbagai gaya bebahasa. Hal ini karena bahasa merupakan alat atau sarana untuk menyampaikan ide atau gagasan, konsep, dan juga perasaan (Chaer dan Agustina, 2010).

Sementara itu, agar dapat menggunakan bahasa dengan baik dalam proses komunikasi diperlukan dua hal utama, yaitu linguistik dan pragmatik. Linguistik berkaitan dengan ketepatan bentuk dan struktur bahasa sedangkan 
pragmatik berkaitan dengan kecocokan bentuk dan struktur tersebut dengan konteks penggunaannya (Satromiharjo, 2001). Pragmatic is inseparable part of other skills to learn a language (Amna, 2018).

Nurinna Arifiany, Maharani P. Ratna, (2016) menyatakan bahwa pragmatik memiliki beberapa topik yang dapat dibahas. Salah satunya adalah tindak tutur. Tindak tutur terdiri atas berbagai macam, yaitu lokusi (pengungkapan bahasa), ilokusi (maksud), dan perlokusi (dampak atau pengaruh dari ujaran) (Austin, 1962). Pragmatik juga berkaitan dengan studi tentang makna yang disampaikan oleh penutur dan ditafsirkan oleh pendengar (Yule, 2006).

Selain aspek pragmatik, kesantunan berbahasa juga sangatlah penting untuk diperhatikan dalam berkomunikasi. Kesantunan merupakan sebuah istilah yang berkaitan dengan kesopanan, rasa hormat, dan sikap yang baik, atau perilaku yang pantas (Gunawan, 2013). Kesantunan tentunya tidak hanya berkaitan dengan aspek kebahasaan semata, melainkan juga pada aspek sikap. Berbahasa dengan santun merupakan salah satu upaya membentukan dan penguatan karakter yang baik (Mustika).

Hasibuan (2005) menyebutkan bahwa kesantunan berbahasa bertujuan untuk menjaga muka orang lain atau citra diri seseorang di dalam masyarakat. Hal ini selaras dengan teori kesantuan berbahasa yang dicetuskan oleh Brown dan Levinson (1987) yang memberi batasan kesantunan pada upaya menjaga muka atau citra orang lain. Begitu juga halnya dengan Gusriani, dkk (2012) menjelaskan bahwa salah satu upaya mengajarkan kesantunan berbahasa adalah melalui sekolah. Sekolah memiliki andil dalam membentuk kesantunan berbahasa dan guru memiliki peran penting dalam hal ini. Yule (2006) menegaskan bahwa kesantunan berbahasa dapat didefiniskan sebagai alat yang digunakan untuk menunjukkan muka orang lain. Sementara itu, Leech (1993) mengelompokkan prinsip kesantunan menjadi enam maksim, yaitu maksim kearifan, kedermawanan, pujian, kerendahan hati, pemufakatan, dan simpati.

Bejeghum merupakan salah satu kebudayaan masyarakat Kedurang yang ada di Bengkulu Selatan yang melibatkan bahasa di dalamnya. Bahasa menjadi inti dari kebudayaan ini. Bejeghum merupakan kegiatan mengundang masyarakat yang dilakukan dengan cara mendatangi individu secara langsung dengan maksud untuk mengajak atau memberitahukan suatu informasi kepada orang lain. Kegiatan ini masih berlangsung hingga sekarang. Bejeghum menggunakan bahasa daerah, khususnya bahasa Pasemah pada masyarakat Kedurang di Bengkulu Selatan.

Sebagai kegiatan kebudayaan yang melibatkan bahasa, bejeghum tentunya hal unik yang perlu dijaga eksistensinya. Kegiatan ini merupakan bagian dari budaya lokal yang perlu dilestarikan. Bejeghum diselenggarakan secara terencana dan juga terkadang dilakukan secara spontan. Hal ini bergantung dengan jenis tujuan dan kondisi yang terjadi. Akan tetapi, hal ini tentunya tidak memengaruhi esensi dari kegiatan bejeghum tersebut.

Seperti sudah dijelaskan di atas, eksistensi bejeghum pada masyarakat Kedurang hingga sekarang masih sangat baik. Masyarakat masih melakukan tradisi ini. Belum ada pengikisan kebudayaan yang berarti. Penelitian terhadap kebudayaan bejeghum ini juga belum begitu banyak dilakukan. Peneliti menemukan hanya ada satu penelitian yang membahas budaya bejeghum pada masyarakat Kedurang Bengkulu Selatan. Penelitian tersebut membahas tentang hakikat pelaksanaan bejeghum secara universal. Penelitian tersebut dilakukan oleh Satria Adi Pirnawan pada tahun 2010.

Hasil penelitian tersebut masih membutuhkan kajian lebih lanjut. Jika dalam penelitian tersebut dibahas mengenai pelaksanaan bejeghum, maka 
dalam kesempatan ini, peneliti tertarik untuk fokus melakukan penelitian tentang fungsi bahasa dalam proses pelaksanaan budaya bejeghum pada masyarakat Kedurang di Bengkulu Selatan. Peneliti berharap bahwa penelitian ini memberikan sumbangsih bagi keilmuan linguistik dan budaya, serta sebagai upaya pelestarian kebudayaan yang ada di Kedurang Bengkulu Selatan.

\section{METODE PENELITIAN}

Dalam penelitian ini, peneliti menggunakan penelitian kualitatif. Penelitian yang dilakukan semata-mata hanya berdasarkan fakta yang ada atau fenomena yang secara emperis hidup pada penutur-penuturnya, sehingga yang dihasilkan atau yang dicatat berupa perian bahasa yang biasanya dikatakan sifatnya seperti potret dan paparan seperti adanya (Sudaryanto, 1986:62). Nazir (1986:63) juga berpendapat bahwa metode deskriptif adalah metode dalam penelitian sekelompok manusia, suatu objek, suatu sistem pemikiran yang bertujuan mendeskripsikan atau melukiskan secara sistematis, faktual atau akurat mengenai fakta, serta hubungan antar fenomena yang diselidiki.

Peneliti merupakan instrumen utama. Dalam hal ini, untuk mendapatkan data yang valid dan benar-benar diperlukan, peneliti menggunakan beberapa teknik pengumpulan data seperti observasi, wawancara kepada beberapa orang infroman yang merupakan masyarakat asli Kedurang yang memilki wawasan kebudayaan terhadap kebudayaan Kedurang, dan terakhir adalah perekaman. Observasi dan wawancara dilakukan secara mendalam untuk mendapatkan informasi yang akurat.

Penelitian mengenai bejeghum ini dilakukan di daerah Kedurang, Kabupaten Bengkulu Selatan. Pemilihan di daerah Kedurang ini sebagai tempat atau lokasi penelitian berdasarkan wilayah penutur bahasa Pasemah. Data dikumpulkan melalui wawacara kepada para informan secara mendalam dan juga melalui observasi. Mahsun (2007:30) mendefinisikan informan sebagai sampel penutur atau orang yang ditentukan di wilayah pakai varian bahasa tertentu sebagai narasumber bahan penelitian, pemberi informasi, dan pembantu peneliti dalam tahap penyediaan data. Orangorang yang dipilih ini didasarkan atas pertimbangan tertentu, sesuai dengan tujuan penelitian dan harus benar-benar sadar akan perannya sebagai narasumber yang pada hakikatnya sebagai alat pemeroleh data. Informan yang dipilih dalam penelitian ini adalah mereka yang memenuhi kriteria atau persyaratanpersyaratan untuk menjadi informan a) dewasa; b) memiliki daya ingat yang baik; c) jujur, yaitu mampu memberikan keterangan berdasarkan kenyataan yang sebenarnya; d) sehat jasmani dan rohani; e) mampu berkomunikasi dengan baik; f) penutur asli bahasa Pasemah di Bengkulu Selatan; g) penduduk asli Kedurang Bengkulu Selatan.

\section{HASIL PENELITIAN DAN PEMBAHASAN}

\section{Bejeghum pada Masyarakat Kedurang Bengkulu}

Pirnawan (2010:23) menyatakan bejeghum 'mengundang' berasal dari kata dasar jeRum yang dalam bahasa Pasemah bermakna 'undang' yang mendapat afiks be- sehingga menjadi bejeRum yaitu melakukan suatu kegiatan mengundang. Dalam bahasa Pasemah, orang yang bejeRum 'mengundang' disebut penjeRum 'pengundang'. Berdasarkan observasi dan wawancara yang dilakukan, bejeghum pada masyarakat Kedurang di Bengkulu memiliki beberapa karakteristik. Umunya bejeghum terdiri atas bejeghum untuk mengundang kedatangan pada acara resepsi pernikahan, syukuran, memperingati kematian, dan gotongroyong.

Jika ditinjau dari pelakunya, bejeghum dilakukan oleh perempuan yang sudah menikah. Kegiatan bejeghum tidak 
pernah dilakukan oleh seorang gadis, syarat ini merupakan syarat mutlak adat masyarakat setempat yang harus dipatuhi. Jika ditinjau dari sifat informasinya, bejeghum dapat berupa kabar bahagia maupun kabar duka. Kabar bahagia seperti undangan untuk menghadiri acara pernikahan, syukuran rumah baru, dan undangan jenis lainnya. Kabar duka biasanya berupa bejeghum yang memberitahu ada orang yang mennggal dunia.

Jika ditinjau dari urgensinya, bejeghum dapat berupa mendesak maupun santai. Bejeghum yang mendesak berarti meminta yang diundang agar segera memenuhi undangan bebrapa saat setelah diundang. Hal ini berupa kabar duka seperti kabar kematian atau acara gotong royong. Semenatra itu, bejghum yang bersifat santai adalah bejghum mengenai acara pernikahan. Hal ini biasanya mengundang untuk datang seminggu berikutnya. Yang diundang pun harus mengingat baik-baik undangan tersebut.

Jika ditinjau dari waktu pelaksanaannya, bejeghum dilaksanakan pada pagi atau sore. Hal ini karena masyarakat di Kedurang mayoritas bekerja sebagai petani. Pagi atau sore hari adalah waktu yang efektif untuk menemui mereka. Bejeghum sangat jarang dilaksanakan pada siang hari, kecuali dalam kondisi tertentu seperti mengabarkan kabar duka. Dari segi tempat pelaksanaannya, bejeghum dilaksanakan di rumah atau di teras rumah. Bejeghum dilakukan dengan mendatangi rumah warga satu per satu. Yang diutus untuk melakukan kegiatan bejeghum baisanya kerabat dari yang mengundang. Ia akan mendatangi setiap rumah yang ada di desa di Kedurang untuk menuntaskan amanah tersebut. Kegiatan ini dilakukan tidak begitu formal sehingga pelaksanaannya bisa saja di luar rumah atau halaman, di teras, ataupun di dalam rumah.

Jika ditinjau dari sasarannya, bejeghum biasanya dilakukan kepada orang tua ataupun orang yang sudah cukup akalnya. Jika orang tua dari rumah yang dituju sedang tidak ada di rumah, maka bejeghum dapat disampaikan kepada anaknya yang sudah cukup akal untuk mengingat informasi yang disampaikan dari kegiatan bejeghum tersebut. Hal ini karena bejeghum berisi bebarapa informasi penting mengenai waktu pelaksanaan informasi yang disampaikan.

Jika ditinjau dari tujuannya, bejeghum bertujuan untuk mengajak bergotong-royong, memberitahu acara pernikahan, mengabarkan kabar duka, dan undangan untuk mempererat persaudaraan. Berikut secara rinci digambarkan jenisjenis bejeghum yang ada pada masyarakat Kedurang di Bengkulu Selatan.

a. Kabar pernikahan

Ini dilakukan untuk mengundang acara pernikahan. Biasanya dilakukan seminggu sebelum perniakahan berlangsung.

b. Kabar Kematian

Untuk meninformasikan berita duka dan meminta yang diundang untuk segara datang ke rumah duka.

c. Ngayikkah anak

Tradisi ini merupakan pesta syukuran karena sudah punya anak. Hal ini dilakukan dua kali. saat masih bayi dan mengnjak remaja.

d. Setulungan

Biasanya dilakukan pada kondisi tertentu, yaitu untuk gootng royong membantu salah satu anggota masyarakat. Misal membuatkan tempat tinggal, memasak sebelum resepsi pernikahan, dan acara lainnya.

e. Pantauan

Ini merupakan adat wajib bagi kaum laki-laki. Dilakukan pada pagi, siang, atau malam hari. Dilakukan pada bejeghum nikahan, syukuran, njamu lebaran, dan memperingati kematian.

$f$. Syukuran atau mbayar niat

Ini dilakukan sebagai bentuk rasa syukur terhadap tuhan yang maha esa. Misal bersyukur karena mempunyai rumah baru, mobil baru, atau berhasil mendapatkan apa yang dimau. 


\section{g. Njamu lebaran}

Ini dilakukan hanya apda momen lebara, baik idul fitri maupun idul adha.

h. Njamu memperingati hari kematian

Terdiri atas nige aghi dan ngempat puluh, yaitu memperingati tiga hari dan empat puluh hari sejak meninggalnya seseoarang.

Selanjutnya, sebagaimana sudah disebutkan senelumnya bahwa tidak semua orang dapat melakukan kegiatan bejeghum. Berdasarkan hasil wawancara yang dilakukan dengan beberapa narasumber, biasanya orang yang menjadi penjeghum atau pengundang merupakan orang-orang pilihan yang dasar pemilihannya sesuai dengan kriteria adat Pasemah dan ditunjuk langsung oleh keluarga yang mengadakan acara berdasarkan rapat keluarga. Dengan kata lain, kegiatan bejeRum 'mengundang' tidak boleh dilakukan dengan orang-orang sembarangan. Hal ini karena bejeghum merupakan adat, maka sudah pasti seorang penjeghum 'pengundang' harus memenuhi syarat-syaratnya sesuai adat Pasemah. Adapun syarat-syarat penjeghum tersebut adalah perempuan, sudah menikah, merupakan kerabat dekat dari yang mengadakan acara, menggunakan pakaian yang sopan, memiliki kemampuan berbicara yang baik, dan bisa bersosialisasi dengan baik dengan orang lain.

Fungsi Bahasa dalam Komunikasi Adat Bejeghum (Kajian Sosiopragmatik)

Ode (2015) menjelaskan bahwa sosiopagmatik merupakan telaah mengenai kondisi-kondisi setempat dan kondisikondisi lokal yang lebih khusus mengenai penggunaan bahasa. Bertemali dengan hal tersebut, penggunaan bahasa tentunya memiliki maksud atau tujuan dan sebaiknya disampaikan secara santun. Semakin tembus pandang maksud sebuah tuturan akan semakin langsunglah tuturan tersebut. Jika dikaitkan dengan kesantunan, semakin jelas maksud sebuah tuturan akan semakin tidak santunlah tuturan tersebut, sebaliknya jika semakin tidak tembus pandang maksud sebuah tuturan, akan semakin santunlah tuturan itu (Anggraini, 2005).

Satuan yang dianalisis oleh pragmatik bukanlah kalimat, melainkan tindak ujar atau tindak tutur yang disebut speech act. Leech (1883) menyatakan bahwa pragmatik berurusan dengan tindak-tindak atau performansiperformansi verbal yang terjadi dalam situasi dan waktu tertentu, sedangkan tata bahasa berurusan dengan wujud-wujud statis yang abstrak (abstract static entities) dan proposisi (dalam semantik). Senada dengan hal tersebut, Ibrahim (1993) menyatakan bahwa tindak tutur harus dibedakan dari kalimat karena tindak tutur tidak dapat diidentifikasi dengan satuan kebahasaan dan satuan gramatika apapun.

Fraser (1990) menyatakan bahwa ada beberapa pandangan yang dapat digunakan untuk mengkaji kesantunan dalam bertutur. Pertama, pandangan kesantunan bertutur ditentukan oleh norma-norma dan kultural yang berlaku dalam masyarakat. Kedua, pandangan yang melihat kesantuan sebagai sebuah maksim percakapan dan sebagai upaya penyelamatan muka. Demikian halnya dengan teori yang dikemukakan oleh Brown dan Levinson (1978) yaitu pandangan penyelamatan muka. Teori lain yang sangat komprehensif dan dikenal adalah teori Leech (1983) yang menyatakan bahwa pragmatik adalah bidang linguistik yang mengkaji makna dalam hubungannya dengan situasi-situasi tutur. Hal ini berarti bahwa makna dalam pragmatik adalah makna eksternal, makna yang terkait konteks, makna yang bersifat tradis (Wijana 1996). Dengan demikian, pragmatik diartikan sebagai bidang linguistik yang mengkaji maksud ujaran. Selain itu, kesopanan dalam berbahasa merupakan hal penting yang perlu diperhatikan.

Berkaitan dengan penggunaan bahasa oleh masyarakat Bengkulu, Junaidi (2017) meneliti tentang penggunaan bahasa pada komunikasi adat berasan bekule di Kedurang. Hasil riset tersebut 
menunjukkan bahwa kegaitan berasan bekule dilakukan secara sistematis dan mengandung banyak ragam bahasa seperti ungkapan, pantun, dan frasa tertentu yang menjadi ciri khas kegiatan tersebut.

Artikel yang ditulis oleh Zakaria dan Rosa (2017) yang mana mereka meneliti kesantunan berbahasa di salah satu pasar di Bengukulu. Zakaria dan Rosa (2017) menyatakan bahwa bahasa yang digunakan oleh pedagang dan pembeli di Pasar Ikan Kota Bengkulu sudah menerapkan enam prinsip kesantunan berbahasa saat berkomunikasi, yaitu maksim kebijaksanaan, maksim kedermawanan, penghargaan, maksim kesederhanaan, pemufakatan/kecocokan, dan kesimpatisan.

Peneliti mengacu pada teori Grice. Hal ini sebagaimana dikemukakan oleh Grice bahwa prinsip kesantunan berbahasa dalam berkomunikasi meliputi enam maksim, yaitu maksim kebijaksanaan, kedermawanan, penghargaan, maksim kesederhanaan, pemufakatan/kecocokan, dan kesimpatisan.

Selain itu, bahasa pada dasarnya berfungsi sebagai media berkomunikasi dalam suatu masyarakat. Bahasa digunakan untuk menyampaikan pesan yang tidak terlepas dari tujuan. Pesan tersebut juga tidak terlepas dari makna yang tersirat maupun tersurat. Menurut Halliday (Sukino, 2004: 32) fungsi bahasa dikelompokan atas tiga bagian, yaitu: (1) Fungsi ideasional merupakan fungsi bahasa yang berkaitan dengan peran bahasa untuk penggunaan isi, pengungkapan pengalaman penutur tentang dunia nyata, termasuk dunia dalam diri kesadaran sendiri. Fungsi ini dilandasi adanya pemikiran bahwa bahasa digunakan untuk mengggambarkan pengalaman, (2) Fungsi interpersonal berkaitan dengan peran bahasa untuk membangun dan memelihara hubungan sosial, untuk mengungkapkan peran-peran sosial termasuk peran komunikasi yang diciptakan oleh bahasa itu, (3) Fungsi tekstual berkaitan dengan tugas bahasa untuk membentuk berbagai mata rantai unsur situasi (features of the situation) yang memungkinkan digunakan bahasa oleh pemakainya.

Selanjutnya, Chaer dan Agustina (2004:12) juga membagi fungsi-fungsi bahasa dari beberapa sudut pandang yang dapat dilihat dari sudut penutur, pendengar, topik, kode, dan amanat pembicara.

1. Dilihat dari segi penutur bahasa itu berfungsi personal, yaitu si penutur menyatakan sikap terhadap apa yang dituturkannya.

2. Dilihat dari segi pendengar maka bahasa itu berfungsi direktif yaitu mengatur tingkah laku pendengar. Di sini bahasa tidak hanya membuat si pendengar melakukan sesuatu, tetapi melakukan kegiatan yang sesuai yang dimaui si pembicara. Hal ini dapat dilakukan penutur dengan menggunakan kalimat-kalimat yang menyatakan perintah, himbauan, permintaan, maupun rayuan.

3. Dilihat dari segi penutur dan pendengar bahasa berfungsi sebagai fatik yaitu fungsi menjalan hubungan, memelihara, memperlihatkan perasaan bersahabat dan solidaritas sosial.

4. Dilihat dari segi topik ujaran maka bahasa itu berfungsi referensial, yaitu bahasa berfungsi sebagai alat untuk membicarakan objek atau peristiwa yang ada di sekeliling penutur atau yang ada pada budaya umumnya.

5. Dilihat dari segi kode bahasa berfungsi metalingual atau metalinguistik yakni bahasa itu digunakan untuk membicarakan bahasa itu sendiri.

Dari data yang diperoleh, bejeghum memiliki fungsi bahasa yang bervariasi. Budaya bejeghum dapat berfungsi sebagai fungsi ideasional. Hal ini karena budaya bejeghum bermaksud menyampaikan ide yang sudah menjadi konvensi masyarakat. Ide tersebut bukan ide secara personal, melainkan hal yang sudah lazim dan diketahui oleh masyarakat. Dalam hal ini, substansi yang disampaikan merupakan 
hari diselenggarakannya acara yang harus diingat oleh orang yang diundang. Akan tetapi, pola komunikasi dalam bejeghum tetap akan sama. Struktur pesan yang disampaiakan pun sudah diketahui. Substansi dari pesan tersebut merupakan aspek yang membedakan setiap kegiatan bejeghum yang dilakukan oleh orang yang mengundang. Artinya, setiap kegiatan bejeghum pada dasarnya memiliki merupakan representasi dari kebudayaan masyarakat yang sudah menjadi ide universal dan konvensi masayarakat di Kedurang, Bengkulu Selatan.

Selanjutnya, jika ditinjau dari sudut penutur, bahasa yang digunakan pada kegiatan bejeghum ini dapat berfungsi sebagai fungsi personal. Dalam hal ini, penutur menyatakan sikap terhadap apa yang dituturkannya.

01:Assalamualaikum. Tape kulagh

Mang?'Santai nian pecaknye.Anu Mang, aku ndik kah masuk agi. Aku ke sini diajungkah Ibung Susi, ndak ngajung kamu balik ke Rumahe mbak kinilah karene Dodi ninggal siang tadi. Itu saje au Mang. 'Begini Paman, saya tidak akan masuk lagi. Saya disuruh Bapaknya Susi, beliau menyuruh Mamang pulang ke rumahnya sekarang karena Nita meninggal siang tadi jam 8 . Itu saja Paman'.

02: Innalillah. Ui au, aku kah kesitu mbak kinilah. 'Innalillah. Iya saya akan segera ke sana'.

Dari kutipan di atas, dapat dilihat bahwa orang yang mengundang atau pengundang tergolong memiliki sikap yang sangat santun. Hal ini dapat dilihat ketika ia mengucapkan salam terlebih dahulu sebelum memulai kegiatan bejeghum. Hal ini menunjukkan bahwa ia memahami norma agama Islam yang ia anut. Bahkan, ia juga menyampaikan frasa santai nian mang "lagi bersantai ya Mang" yang berarti bahwa ia menyapa dengan hangat orang yang ditemui. Ia menunjukkan sikap bersahabat dengan lawan tuturnya. Ia juga menggunakan sapaan Mang atau Mamang yang berarti paman. Hal ini juga menunjukkan sikap kesantunan berbahasa pengundang. Sapaan Mang diujarkan untuk memanggil adik laki-laki dari ibu. Sapaan kekerabatan tersebut merupakan sapaan yang berasal dari bahasa Pasemah.

Selanjutnya, penggunaan frasa dide ka masuk agi pada kutipan di atas juga menyatakan maksim kebijaksanaan penutur. Frasa ini secara tersirat berati bahwa pengundang tidak bsia berlamalama atau menolak untuk diajak berbincang lebih jauh. Namun, ia menyampaikan secara santun dan bahkan tersirat. Sikap ini dilakukan karena pengundang tentunya memiliki tanggung jawab untuk menyelesaikan tugas tersebut. Ia bertanggung jawab untuk mendatangi semua orang yang disuruh oleh pihak keluarga yang menyuruhnya. Dalam melaksanakan tugas tersebut, pengundang tentunya merasakan lelah atau haus, namun ia tetap menolak jikalau ada tawaran untuk minum karena harus menyelesaikan tugas yang diembannya.

Kutipan di atas merupakan contoh bejghum yang berisi kabar duka dan meminta yang diundang agar segera datang. Hal ini ditunjukkan pada kalimat "Aku ke sini diajungkah Ibung Susi, ndak ngajung kamu balik ke Rumahe mbak kinilah karene Dodi ninggal siang tadi" dan respons dari yang diundang yang akan memenuhi undangan tersebut yang dapat dilihat pada kalimat atau respons pembaca "Innalillah. Ui au, aku kah ke situ mbak kinilah".

Jika ditinjau dari pendengar, maka bahasa bejeghum juga berfungsi untuk mengatur respons pendengarnya. Pengundang atau orang yang melaksanakan kegiatan bejeghum bermaksud agar orang yang diundang bukan sekadar memahami informasi yang disajikan melainkan agar mereka mengikuti apa yang mereka inginkan, yaitu mendatangi undangan tersebut. Hal ini dapat dilihat pada kutipan berikut.

01: Ui Nek, langsung saje au Nek. Aku ni diajungka Iman. Die minta tolong kite 
setulungan kudai ngilukki rumahnye akap pagi. "Ui Nek, langung saja ya Nek. saya disuruh oleh Iman. Dia minta tolong agar kita gotong-royong memperbaiki rumahnya besok pagi”.

02: Ui au. Lasung. Akap pagi aku ke sane. "Oh ya. Baik. Besok pagi saya kesana"

Kutipan di atas adalah bejghum dengan tujuan untuk gotong-royong, khususnya membantu memperbaiki rumah slaah seorang anggota masyarakat. Dari kutipan di atas, kita dapat membaca bahwa pendengar merespons dengan baik apa yang disampaikan. Ia akan mengikuti apa yang dikatakan oleh pengundang dengan cara akan datang ke acara gotong-royong tersebut. Hal ini dapat dilihat pada kalimat "Ui au. Lasung. Akap pagi aku ke sane". Sikap ini menjunjukkan bahwa pendengar akan memenuhi permintaan pengundang. Selain itu, penggunaan frasa 'langsung saje" pada kutipan di atas sama halnya dengan frasa 'ndik ka masuk agi' pada kutipan sebelumnya yang berarti langsung saja atau tidak akan berlama-lama. Hal ini mengindikasikan bahwa kegiatan bejeghum memang dilaksanakan dengan cepat dan tanpa adanya obrolan lebih di luar tujuan dari bejeghum tersebut.

Jika ditinjau dari penutur dan pendengar, bahasa yang digunakan pada kegiatan bejeghum berfungsi fatik, yaitu menunjukkan hubungan bersahabat antara keduanya. Hal ini dapat dilihat pada kutipan berikut.

01: Asslammualaikum. Mane jemenye tini ah? Ui Uwak. "Assalammualaikum. Mana orangnya ini ya? Ui Uwak.

02: Walaikumslaam. Ui, au kudai tunggu. Dang di belakang. "Walaikumsalam. Oh ya, tunggu sebentar. Lagi di belakang.

01: Au lasung Uwak. "Ya, tidak apa-apa, Uwak".

02: Nah Diti. Ngape ah? "Nah ada Diti, ada apa ya?".

01: Jadi luk ini Uwak. Aku ni diajungkan rumah Bacik Ari. Die ka njamuka nikahan anaknye ye bename Aan tu minggu depan. Jadinye aghi Sabtu nga minggu. Jadi die ndak ngajung kamu sekeluarge nak beranak balik kudai ke rumahnye au Uwak. "Jadi begini, Uwak. Aku disuruh Paman Ari. Dia akan mengadakan resepsi pernikahan anaknya yang bernama Aan minggu depan. Acaranya hari sabtu dan minggu. Jadi, Paman Ari meminta Uwak dan keluarga untuk pulang dulu ke rumahnya".

02: Au jadi. La nyelah itu amu la disampaikah. "Ya. Sudah benar dan jelas kalau sudah diampaikan undangannya".

01: Au uwak. Aku langsung pamit amu luk itu. "Ya, Uwak. Aku langsung pamit ya Uwak"

Data bejeghum di atas adalah jenis bejeghum yang bertujuan untuk mengundang ke acara pernikahan. Dari data di atas, selain ditunjukkan dengan piranti lingusitik, penutur bahasa bejeghum tentunya juga menyampaikan informasi dengan mimik muka yang ramah, senyum, bersahabat, dan sangat santun. Jika sebelumnya menggunakan frasa 'langsung saje' dan "ndik ka masuk agi" sebagai penolakan untuk mengobrol lebih jauh. Maka dari data di atas, pengundang menggunakan frasa "jadi luk ini" untuk langsung memulai kegiatan bejeghum. Frasa 'jadilah luk ini" mengandung arti "jadi begini" yang bermaksud bahwa pengundang akan langsung memulai kegiatan bejeghum. Hal ini disambut dengan baik oleh pendengar atau orang yang diundang. Hal ini terbukti dengan respons pendengar dengan menggunakan frasa "la nyelah amu la disampaikah" yang berarti "terima kasih sudah disampaiakan". Tidak hanya itu, pada bagian akhir juga terdapat frasa yang bertujuan untuk mengakhri obrolan agar tidak membahas hal lain selain informasi yang ia sampaikan. Frasa tersebut adalah "aku langsung pamit" yang berarti bahwa penutur akan langsung pamit dan akan melanjutkan tanggungjawabnya untuk 
menemui orang berikutnya. Hal ini dapat dilihat pada kutipan berikut.

01: Aku ka langsung pamit au, Bung. Itulah ye kusampaika. "Saya langsung pamit ya, Bung. Hanya itu yang prlu saya sampaikan'

02: Au, gila amu ndik ka singgah agi. "Ya, tidak apa-apa kalau begitu".

Dari data di atas, terlihat bahwa secara sosiopragmatik, penjeghum mngakhiri tuturannya dengan kalimat yang khas dan dipahai oleh lawan tuturnya. Pnjeghum tidak secara langsung mengakhiri obrolan melainkan dengan bahasa yang halus dan dipahami oleh lawan tuturnya bahwa ia tidak bisa mengobrol lebih lama lagi karena harus menyelesaikan tanggungajwab berikutnya.

\section{SIMPULAN}

Bejeghum pada masyarakat Kedurang di Bengkulu memiliki banyak variasi, di antaranya bejeghum untuk mengundang kedatangan pada acara resepsi pernikahan, syukuran, memperingati kematian, dan gotong-royong. Bejeghum bisa bertujuan mengabarkan kabar bahagia maupun sedih. sifat informasinya juga bisa bersifat mendesak maupun santai. Kegiatan bejeghum dilakukan oleh perempuan yang sudah menikah yang merupakan kerabat keluarga yang mengutus.

Berdasarkan hasil analisis yang sudah dilakukan. Fungsi bahasa pada kegiatan bejeghum merupakan fungsi ideasional karena budaya ini bertujuan untuk menyampaikan ide yang sudah menjadi konvensional masyarakat. Hal yang membedakan antara kegiatan bejeghum yang satu dengan yang lainnya adalah substansi informasi yang disampaikan. Selanjutnya, jika dilihat dari sudut penutur, bahasa pada kegiatan bejeghum berupa ajakan, ditinjau dari segi pendengar berupa perintah, dan jika ditinjau dari segi kontak antara penutur dengan pendengar berfungsi untuk menjalin kontak sosial.

\section{REFERENSI}

Amna, Shally. (2018). Identifying Pragmatic Failures in Dialogue Scripts of EFL Learner. Journal of Language Education Development. Vol 1, No 1.

Austin, J.L. (1962). How to Do Things with Words. Britain: Oxford Unuversity Press.

Arifiany, Nurinna, Maharani P. Ratna, dan S.I Trahutami. (2016). Pemaknaan Tindak Tutur Direktif dalam Komik "Yowamushi Pedal Chapter 87-93". Jurnal Japanese Literature. Vol 2, No 1.

Biçer, N. (2017). The Views of Syrian Refugees Migrating to Turkey on the Turkish Language and Culture: Kilis Case. Journal of Education and Training Studies. https://doi.org/10.11114/jets.v5i3.210 0

Brown dan Levinson. (1978). Universal in Language Usage: Politeness Phenomena. Cambridge: Cambridge University Press.

Chaer, Abdul dan Leonie Agustina. (2010). Sosiolinguistik Perkenalan Awal. Jakarta: Renka Cipta.

Chaer, A. dan Agustina, L. (2004). Sosiolinguistik Perkenalan Awal. Jakarta: PT Rineka Cipta.

Fraser, B. (1990). Perspectives on politeness. Journal of Pragmatics. https://doi.org/10.1016/03782166(90)90081-N

Gunawan, F. (2013). Wujud Kesantunan Berbahasa Mahasiswa terhadap Dosen di STAIN Kendari: Kajian Sosiopragmatik. JURNAL ARBITRER. https://doi.org/10.25077/ar.1.1.818.2013

Gusriani, Nuri, Atmazaki, dan Ellya Ratna. (2012). Kesantunan Berbahasa Guru Bahasa Indonesia dalam Proses Belajar Mengajar di SMA Negeri 2 Lintau Buo. Jurnal Pendidikan 
Bahasa dan Sastra Indonesia. Vol 1, No 1.

Hasibuan, N. H. (2005). Perangkat Tindak Tutur dan Siasat Kesantunan Berbahasa (Data Bahasa Mandailing). Logat: Jurnal Ilmiah Bahasa Dan Sastra.

Ibrahim. Abd. Syukur. (1993). Kajian Tindak Tutur. Surabaya: Usaha Nasional.

Junaidi, Febi. (2017). The role of berasan bekule culture as the customary law within the society of Pasemah in Bengkulu Selatan. Yogyakarta. IIFAS Proceeding.

Leech, Geoffrey N. (1983). Principles of Pragmatic. London: Longman.

Leech, Geoffrey N. (1993). PrinsipPrinsip Pragmatik. Jakarta: Universitas Indonesia.

Mahsun. (2007). Metode Penelitian Bahasa. Jakarta: PT Raja Grafindo.

Mustika, Ika. Mentradisikan Kesantunan Berbahasa: Upaya Membentuk Generasi Bangsa yang Berkarakter. SEMANTIK: Jurnal Ilmiah Program Studi Pendidikan Bahasa dan Sastra Indonesia. STKIP Siliwangi Bandung.

Nadera, B. (2018). Integrating Cultural Activities in the Algerian Language Classroom: On The Move Textbook. Advances in Language and Literary Studies. https://doi.org/10.7575/aiac.alls.v.9n. 5 p. 65

Nazir, Moh. Metode Penelitian. Jakarta: Ghalia.

Nurinna Arifiany, Maharani P. Ratna, S. I. T. (2016). Pemaknaan Tindak Tutur Direktif Dalam Komik "Yowamushi Pedal Chapter 87-93." Journal of Chemical Information and Modeling.

ODE, W. N. (2015). Kesantunan Berbahasa Indonesia Dalam Lingkungan Keluarga (Kajian Sosiopragmatik). Jurnal Humanika.

Oxford, R. L., \& Gkonou, C. (2018). Interwoven: Culture, language, and learning strategies. Studies in Second
Language Learning and Teaching. https://doi.org/10.14746/ssllt.2018.8. 2.10

Rahardi, Kunjana. (2005). Pragmatik Kesantunan Imperatif Bahasa Indonesia. Yogyakarta: Airlangga.

Sari, F. D. P. (2012). Tindak Tutur dan Fungsi Tuturan Ekspresif Dalam Acara Galau Nite Di Metro Tv: Suatu Kajian Pragmatik. Skriptorium.

Sastromiharjo, Andoyo. (2001). Kesalahan Pragmatik Pembelajar BIPA. Makalah. Oktober 2001. Bali.

Sudaryanto. (1988). Metode Linguistik. Yogyakarta: Gadjah Mada University Press.

Sukino. (2004). Memahami Wacana Bahasa Indonesia. Bengkulu: Unib Press.

Wijana, I Dewa Putu. (19960. DasarDasar Pragmatik. Yogyakarta: Andi.

Yule, George. 2006. Pragmatik. Edisi Terjemahan oleh Fajar Wahyuni. Yogyakarta: Pustaka Pelajar.

Zakaria, Jelita dan Rosa Apria Gustiani. (2017). Kesantunan Berbahasa Pedagang dalam Transaksi Jual Beli di Pasar Ikan Kelurahan Pasar Bengkulu Kota Bengkulu. LITERALISASI: Jurnal Bahasa dan Sastra Indonesia. Vol 5, No 2. 